\title{
Inventory and comparison of abundance of parasitic copepods on fish hosts in the western Wadden Sea (North Sea) between 1968 and 2010
}

\author{
WOUTER KOCH, PETER BOER, JOHANNES IJ. WITTE, HENK W. VAN DER VEER \\ AND DAVID W. THIELTGES \\ ${ }^{1}$ Department of Marine Ecology; NIOZ Royal Netherlands Institute for Sea Research; PO Box 59, 1790 AB Den Burg Texel, \\ The Netherlands
}

\begin{abstract}
A conspicuous part of the parasite fauna of marine fish are ectoparasites, which attach mainly to the fins or gills. The abundant copepods have received much interest due to their negative effects on hosts. However, for many localities the copepod fauna of fish is still poorly known, and we know little about their temporal stability as long-term observations are largely absent. Our study provides the first inventory of ectoparasitic copepods on fish from the western Wadden Sea (North Sea) based on field data from 1968 and 2010 and additional unpublished notes. In total, 47 copepod parasite species have been recorded on 52 fish host species to date. For two copepod species parasitizing the European flounder (Platichthys flesus), a quantitative comparison of infection levels between 1968 and 2010 was possible. Whereas Acanthochondria cornuta did not show a change in the relationship between host size and infection levels, Lepeophtheirus pectoralis shifted towards the infection of smaller hosts, with higher infection levels in 2010 compared to 1968. These differences probably reflect the biology of the species and the observed decrease in abundance and size of flounders during the last decades. The skin-infecting L. pectoralis can probably compensate for dwindling host abundance by infecting smaller fish and increasing its abundance per given host size. In contrast, the gill cavity inhabiting A. cornuta probably faces a spatial constraint (fixed number of gill arches), thus limiting its abundance and setting a minimum for the host size necessary for infections.
\end{abstract}

Keywords: parasitism, long-term data, parasite fauna, fish hosts, coastal waters

Submitted 25 September 2012; accepted 26 October 2013; first published online 13 December 2013

\section{INTRDDUCTION}

Parasites are a ubiquitous but inconspicuous part of ecosystems that has largely been overlooked in ecological studies. In recent years, ecologists have increasingly recognized the importance of parasites for host populations, ecological communities, and the dynamics of entire food webs (e.g. Sousa, 1991; Mouritsen \& Poulin, 2002; Sukhdeo, 2012). This also holds true for the ectoparasitic copepods of marine fish, a group of parasites with a diverse range of host species, life histories and impacts. For example, much attention has been devoted to sea lice, which are copepods parasitic on farmed salmon, due to the particularly detrimental effects on these economically valuable stocks (Tully \& Nolan, 2002) but also due to their dramatic effects on wild salmon populations via a spill-over from aquaculture farms (Krkošek et al., 2007, 2011). In general, parasitic copepod species are well known and described, especially in the north-east Atlantic (Kabata, 1979, 2003; Möller \& Anders, 1986) and host-parasite lists

Corresponding author:

D.W. Thieltges

Email: David.Thieltges@nioz.nl have been compiled from various regions (e.g. Bere, 1936; Heegaard, 1962; Palm et al., 1999; Boxshall, 2009). However, local inventories and quantitative data sets remain rare and are usually restricted to limited numbers of host species (e.g. Causey, 1960; Groenewold et al., 1996; Schmidt et al., 2003; Kleinertz et al., 2011). In addition, long-term time-series on parasitic copepod faunas are scarce.

Long-term data series on parasitism can be very informative as they help reveal links between the environment and parasite community dynamics. Parasite abundance can be strongly dependent on the presence and abundance of hosts (Poulin et al., 2011). Changes in the diversity and abundance of parasites can thus be indicative of broader changes due to environmental factors affecting hosts, such as pollution, temperature, habitat loss and exploitation of fish stocks (Vidal-Martinez et al., 2010; Wood et al., 2010). For example, altered fish host abundance and distribution, as well as selective removal of hosts as a result of human exploitation, may lead to changes in parasite population dynamics (Wood et al., 2010).

In this study, we present the first qualitative inventory of parasitic copepods from fish in the western Wadden Sea (North Sea) based on field surveys in 1968 and 2010 and additional records from the archives of the NIOZ Royal 
Netherlands Institute for Sea Research. In addition, we investigate quantitative changes in the infection patterns of two copepod species (Acanthochondria cornuta (Müller, 1776) and Lepeophtheirus pectoralis (Müller, 1776)) infecting European flounders (Platichthys flesus (Linnaeus, 1758)), using data from surveys in 1968 and 2010. To link potential changes in parasite infection patterns with changes in host abundance and size, we also analysed long-term data from flounders from the NIOZ fyke net sampling programme $(1960-2011)$.

\section{MATERIALS AND METHDDS}

\section{Acquisition of parasite inventory data}

Observations of host-parasite relationships were retrieved from three sources: (1) archival data from the NIOZ Royal Netherlands Institute for Sea Research where host-parasite relationships observed during ongoing fish surveys in the western Wadden Sea and adjacent North Sea in the first half of the 1900 were noted without reporting a date or sampling effort; (2) an unpublished field survey from 1968 including sampling effort and dates; and (3) a recent field survey undertaken in May to June 2010. In both field surveys, fish were collected from several bottom- and pelagic trawls in the Wadden Sea (inshore) and North Sea (offshore) adjacent to the island of Texel in the western Wadden Sea, The Netherlands. In addition, fish caught in a fyke net located at the south of Texel were added to the sample population in both surveys (for more details on the NIOZ fyke sampling programme see Van der Veer et al., 2011). Both data sets (1968 and 2010) can be considered to be comparable since the fyke net has been located at the same spot in both periods and maps in the respective internal reports indicate that the locations of the trawls were within the same area around the island of Texel.

Parasite investigations were conducted in a similar manner in both field surveys. Captured fish were identified, measured and checked for ectoparasites. In order to find parasites, the skin and fins of the host were examined, after which the skin connected to the gill flaps was incised to allow an inspection of the gill arches. All ectoparasites found were collected, counted and subsequently stored in alcohol in a separate vial per host. Whenever fish could not be examined within $15 \mathrm{~min}$ of capture, they were stored individually in sealed plastic bags at $-20^{\circ} \mathrm{C}$. Parasites were reviewed under magnification and identified to species level using Kabata (2003). Since classification slightly differed in the 1968 survey, when Dogiel et al. (1953) and Scott \& Scott (1912) were used for copepod identification, those parasite species were reassessed to comply with the modern classification and nomenclature as described in Kabata (2003).

\section{Temporal changes in infection patterns and host size and abundance}

The 1968 data contained detailed information on the intensity (number of copepods per infected host) per host size-class of two copepod species found on European flounder (Platichthys flesus) in spring/summer: Acanthochondria cornuta and Lepeophtheirus pectoralis. Similar data for both parasite species from the same season were obtained in 2010, allowing for a comparison of host size-parasite infection level relationships between the two periods. To do so, we plotted the numbers of Acanthochondria cornuta and Lepeophtheirus pectoralis against host length and used an ANCOVA approach to test for significant changes in the slopes of the parasite intensity-host length relationships between the two periods. We tested for differences in prevalence between the two periods using a $\chi^{2}$ test.

Long-term trends in the abundance and size of the flounder hosts (Platichthys flesus) were investigated using data from a long-term time-series conducted by the NIOZ from a fyke net situated at the south of the island of Texel. During spring (April-June) and autumn (September-October) the catch of this fyke net is emptied almost every day (as long as the weather allows) and is considered to be a representative snapshot of the fish fauna occurring in the area (for details see Van der Veer et al., 1992; Van der Meer et al., 1995). We investigated temporal trends in flounder abundance by plotting mean daily catches (ind. $\mathrm{d}^{-1}$ ) between 1960 and 2011. Data on the size of caught flounders were only available from 1975-2011. We plotted the frequency of flounders (total number of individuals) caught per size-class ( $2 \mathrm{~cm}$ bins) grouped into four periods: 1975-1979, 1980-1989, 19901999 and 2000-2011. Since these data only served as background information for interpreting the parasite data, the results were only qualitatively compared without any statistical analysis. Using the mean daily catches in 1968 and 2010, we calculated the density of infected fish (mean daily catches $\times$ copepod prevalence) and the density of copepods (mean daily catches $\times$ copepod abundance), following Hechinger et al. (2008).

\section{RESULTS}

\section{Parasite inventory}

In total, 52 fish species from the waters around Texel belonging to 16 orders were inspected for parasitic copepods (see Table 1). Most of the fish species were only infected by a single copepod species and six species were found not to be infected at all (Figure $1 \mathrm{~A}$ ). However, two host species were infected by up to five copepod species (Merlangius merlangus, Solea solea; Figure 1A). There was a significant positive correlation between the number of individual fish of a species examined (where these data were available) and the number of parasites species found to occur on them (both logtransformed, $R^{2}=0.284, P=0.002$ ), indicating that higher sampling effort increases the number of parasite species found, and that the current sampling effort is not high enough to result in a complete list. In total, 47 parasite species were found in the waters of the western Dutch Wadden Sea (see Table 2). The dominant families were the Caligidae, Chondracanthidae, Lernaeopodidae and Pennellidae. Most parasite species occurred only on a single host species, but some parasite species were found on as many as six different host species (Figure $1 \mathrm{~B}$ ).

\section{Temporal changes in infection patterns and host size and abundance}

The two copepod species Acanthochondria cornuta and Lepeophtheirus pectoralis infecting the European flounder 
Table 1. List of host species by order, and the parasites found on them in the western Wadden Sea. Numbers in square brackets indicate the host sample size in 1968 and 2010, respectively. Question marks in the 1968 data set occur where species were mentioned without quantitative information, referring to the NIOZ archive as the source. A dash is used where that particular host taxon was not included in that year. The distinction between the common goby and the sand goby was not made in 1968, so goby sp. is included to provide a combined 1968 sample size. Host names are in accordance with www.fishbase.org; parasite names follow Kabata (2003). The eight host species not investigated in other studies from the North Sea region (Groenewold et al., 1996; Palm et al., 1999; Schmidt et al., 2003; Boxshall, 2009) are indicated with an asterisk. Name changes compared to the 1968 study due to taxonomic changes are as follows (1968 name=updated name): Acanthochondria depressa=Acanthochondria cornuta; Acanthochondria florae = Acanthochondria cornuta; Bomolochus onosi = Taeniacanthus onosi; Brachiella ovalis = Parabrachiella bispinosa; Caligus rapax $=$ Caligus elongates; Medesicaste triglarum = Lernentoma asellina.

\section{Host-parasite list}

BELONIFORMES

Garfish (Belone belone (Linnaeus, 1761)) [?, 1]: Caligus belones.

CARCHARHINIFORMES

Tope shark* (Galeorhinus galeus (Linnaeus, 1758)) [?, o]: Echthrogaleus coleoptratus, Lernaeopoda bidiscalis, Lernaeopoda galei and Pandarus bicolor. Smooth-hound* (Mustelus mustelus (Linnaeus, 1758)) [?, o]: Lernaeopoda bidiscalis, Lernaeopoda galei, Pandarus bicolor and Tripaphylus musteli. Small-spotted catshark (Scyliorhinus canicula (Linnaeus, 1758)) [?, o]: Lernaeopoda galei.

CLUPEIFORMES

Twaite shad (Alosa fallax (Lacepède, 1803)) [3, o]: Clavellisa emarginata.

Atlantic herring (Clupea harengus Linnaeus, 1758) [2627, 6]: Caligus elongatus, Lepeophtheirus salmonis and Lernaeenicus sprattae.

European sprat (Sprattus sprattus (Linnaeus, 1758)) [2903, 55]: Lepeophtheirus salmonis, Lernaeenicus encrasicholi and Lernaeenicus sprattae.

GADIFORMES

Fivebeard rockling (Ciliata mustela (Linnaeus, 1758)) [3, 1]: none.

Fourbeard rockling (Enchelyopus cimbrius (Linnaeus, 1766)) [?, o]: Taeniacanthus onosi.

Atlantic cod (Gadus morhua Linnaeus, 1758) [15, o]: Caligus curtus, Caligus elongatus and Lernaeocera branchialis.

Haddock (Melanogrammus aeglefinus (Linnaeus, 1758)) [3, o]: Caligus curtus.

Whiting (Merlangius merlangus (Linnaeus, 1758)) [564, 3]: Caligus curtus, Caligus elongatus, Clavella adunca, Lepeophtheirus salmonis and Lernaeocera branchialis.

European hake (Merluccius merluccius (Linnaeus, 1758)) [?, o]: Chondracanthus merluccii and Clavella stellata.

Pollack (Pollachius pollachius (Linnaeus, 1758)) [14, o]: Lernaeocera branchialis.

Saithe (Pollachius virens (Linnaeus, 1758)) [140,3]: Lepeophtheirus pollachius and Lernaeocera branchialis.

Pouting (Trisopterus luscus (Linnaeus, 1758)) [102, 30]: Lernaeocera lusci.

Poor cod* (Trisopterus minutus (Linnaeus, 1758)) [17, o]: Lernaeocera lusci.

LAMNIFORMES

Porbeagle* (Lamna nasus (Bonnaterre, 1788)) [?, o]: Anthosoma crassum and Dinemoura producta. LOPHIIFORMES

Angler (Lophius piscatorius Linnaeus, 1758) [?, o]: Caligus curtus and Chondracanthus lophii.

MUGILIFORMES

Thicklip grey mullet* (Chelon labrosus (Risso, 1827)) [0, 4]: none.

OSMERIFORMES

European smelt (Osmerus eperlanus (Linnaeus, 1758)) [153, 17]: Lernaeocera sp. (juv) and Lernaeocera sp. (larvae).

PERCIFORMES

Small sandeel (Ammodytes tobianus Linnaeus, 1758) [28, 32]: none.

Transparent goby* (Aphia minuta (Risso, 1810)) [1, 2]: Lernaeocera sp. (juv).

Meagre* (Argyrosomus regius (Asso, 1801)) [?, o]: Brachiella thynni and Lernanthropus gisleri.

Dragonet (Callionymus lyra Linnaeus, 1758) [85, 1]: Lernaeocera lusci.

European seabass (Dicentrarchus labrax (Linnaeus, 1758)) [0, 1]: none.

Rock gunnel (Pholis gunnellus (Linnaeus, 1758)) [5, 6]: Haemobaphes cyclopterina and Philorthragoriscus serratus.

Sand goby (Pomatoschistus minutus (Pallas, 1770)) [-, 9]: Lernaeocera minuta.

Goby sp. (Pomatoschistus sp. Gill, 1863) [448, -]: Lernaeocera minuta.

Atlantic horse mackerel (Trachurus trachurus (Linnaeus, 1758)) [39, o]: Caligus pelamydis.

Eelpout (Zoarces viviparous (Linnaeus, 1758)) [151, 6]: Lernaeocera sp. (juv) and Lernaeocera sp. (larvae).

PLEURONECTIFORMES

Witch flounder (Glyptocephalus cynoglossus (Linnaeus, 1758)) [?, o]: Acanthochondria cornuta.

American plaice (Hippoglossoides platessoides (Fabricius, 1780)) [?, o]: Acanthochondria cornuta and Pandarus cranchii.

Common dab (Limanda limanda (Linnaeus, 1758)) [546, 2]: Acanthochondria limandae, Lepeophtheirus pectoralis and Lernaeocera sp. (larvae).

Lemon sole (Microstomus kitt (Walbaum, 1792)) [?, 9]: Acanthochondria clavata and Lernaeocera sp. (larvae).

European flounder (Platichthys flesus (Linnaeus, 1758)) [213, 40]: Acanthochondria cornuta, Lepeophtheirus pectoralis and Lernaeocera sp. (larvae).

European plaice (Pleuronectes platessa Linnaeus, 1758) [614, 36]: Acanthochondria cornuta, Acanthochondria sp., Lepeophtheirus pectoralis and Lernaeocera sp. (larvae)

Turbot (Scophthalmus maximus (Linnaeus, 1758)) [?, o]: Lepeophtheirus pectoralis and Lepeophtheirus thompsoni.

Brill (Scophthalmus rhombus (Linnaeus, 1758)) [3, 1]: Lepeophtheirus pectoralis, Lepeophtheirus thompsoni and Lernaeocera sp. (larvae).

Common sole (Solea solea (Linnaeus, 1758)) [177, 16]: Acanthochondria soleae, Bomolochus soleae, Lernaeocera lusci, Lernaeocera sp. (juv) and

Lernaeocera sp. (larvae).

RAJIFORMES

Blue skate (Dipturus batis (Linnaeus, 1758)) [?, o]: Trebius caudatus.

Thornback ray (Raja clavata Linnaeus, 1758) [?, o]: Lepeophtheirus pectoralis. 
Table 1. Continued.

SALMONIFORMES

Sea trout (Salmo trutta Linnaeus, 1758) [?, 1]: Lepeophtheirus salmonis.

SCORPAENIFORMES

Red gurnard (Chelidonichthys cuculus (Linnaeus, 1758)) [?, o]: Pandarus bicolor.

Tub gurnard (Chelidonichthys lucerna (Linnaeus, 1758)) [28, 3]: Caligus brevicaudatus, Caligus diaphanus and Lernentoma asellina.

Gurnard sp. (Chelidonichthys sp. Kaup, 1873) [?, -]: Caligus gurnardi.

Lumpfish (Cyclopterus lumpus Linnaeus, 1758) [?, o]: Caligus elongatus, Lernaeocera sp. (larvae) and Sphyrion lumpi.

Grey gurnard (Eutrigla gurnardus (Linnaeus, 1758)) [8, o]: Caligus diaphanus, Lernentoma asellina and Parabrachiella bispinosa.

Striped seasnail (Liparis liparis (Linnaeus, 1766)) [5, 5]: none.

Shorthorn sculpin (Myoxocephalus scorpius (Linnaeus, 1758)) [69, 10]: none.

SQUALIFORMES

Picked dogfish (Squalus acanthias Linnaeus, 1758) [?, o]: Pandarus bicolor.

TETRAODONTIFORMES

Ocean sunfish* (Mola mola (Linnaeus, 1758)) [?, o]: Cecrops latreilli, Lepeophtheirus nordmanni, Orthagoriscicola muricatus and Philorthagoriscus serratus.

ZEIFORMES

John dory (Zeus faber Linnaeus, 1758) [?, o]: Chondracanthus zei.

Table 2. List of ectoparasitic copepods by family, and the hosts they have been found on in the western Wadden Sea. Data based on Table 1 . The 23 copepod species found in our study area but not mentioned in previous publications from the North Sea region (Groenewold et al., 1996; Palm et al., 1999; Schmidt et al., 2003; Boxshall, 2009) are indicated with an asterisk.

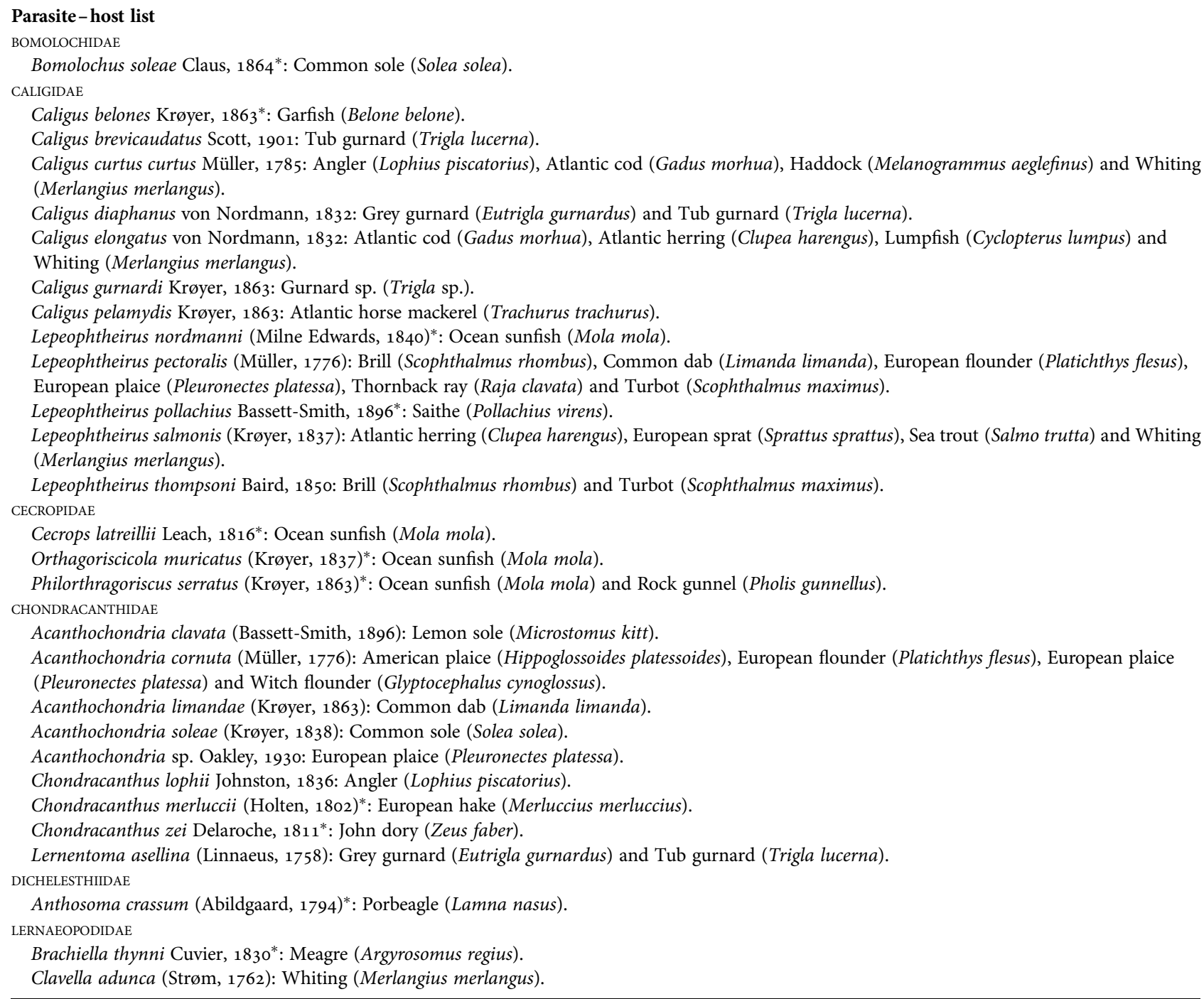


Table 2. Continued.

Clavella stellata (Krøyer, 1838)*: European hake (Merluccius merluccius).

Clavellisa emarginata (Krøyer, 1837): Twaite shad (Alosa fallax).

Lernaeopoda bidiscalis Kane, 1892*: Smooth-hound (Mustelus mustelus) and Tope shark (Galeorhinus galeus).

Lernaeopoda galei Krøyer, 1837*: Small-spotted catshark (Scyliorhinus canicula), Smooth-hound (Mustelus mustelus) and Tope shark (Galeorhinus galeus).

Parabrachiella bispinosa (von Nordmann, 1832): Grey gurnard (Eutrigla gurnardus).

LERNANTHROPIDAE

Lernanthropus gisleri Van Beneden, 1832*: Meagre (Argyrosomus regius).

PANDARIDAE

Dinemoura producta (Müller, 1785)*: Porbeagle (Lamna nasus).

Echthrogaleus coleoptratus (Guérin-Méneville, 1837)*: Tope shark (Galeorhinus galeus).

Pandarus bicolor Leach, 1816: Picked dogfish (Squalus acanthias), Red gurnard (Chelidonichthys cuculus), Smooth-hound (Mustelus mustelus) and Tope shark (Galeorhinus galeus).

Pandarus cranchii Leach, 1819*: American plaice (Hippoglossoides platessoides).

PENNELLIDAE

Haemobaphes cyclopterina (Müller, 1776)*: Rock gunnel (Pholis gunnellus).

Lernaeenicus encrasicholi (Turton, 1807): European sprat (Sprattus sprattus).

Lernaeenicus sprattae (Sowerby, 1806): Atlantic herring (Clupea harengus) and European sprat (Sprattus sprattus).

Lernaeocera branchialis (Linnaeus, 1767): Atlantic cod (Gadus morhua), Pollack (Pollachius pollachius), Saithe (Pollachius virens) and Whiting

(Merlangius merlangus).

Lernaeocera lusci (Bassett-Smith, 1896): Common sole (Solea solea), Dragonet (Callionymus lyra), Poor cod (Trisopterus minutus) and Pouting

(Trisopterus luscus).

Lernaeocera minuta (Scott T., 1900): Sand goby (Pomatoschistus minutus) and Goby sp. (Pomatoschistus sp.).

Lernaeocera sp. Blainville, 1822 (juv): Common sole (Solea solea), Eelpout (Zoarces viviparus), European smelt (Osmerus eperlanus) and Transparent goby (Aphia minuta).

Lernaeocera sp. (larvae): Brill (Scophthalmus rhombus), Common dab (Limanda limanda), Common sole (Solea solea), Eelpout (Zoarces viviparus), European flounder (Platichthys flesus), European plaice (Pleuronectes platessa), European smelt (Osmerus eperlanus), Lemon sole (Microstomus kitt) and Lumpfish (Cyclopterus lumpus).

SPHYRIIDAE

Sphyrion lumpi (Krøyer, 1845)*: Lumpfish (Cyclopterus lumpus).

Tripaphylus musteli (Van Beneden, 1851)*: Smooth-hound (Mustelus mustelus).

TAENIACANTHIDAE

Taeniacanthus onosi (Scott, 1902)*: Fourbeard rockling (Enchelyopus cimbrius). TREBIIDAE

Trebius caudates Krøyer, 1838*: Blue skate (Dipturus batis).

(Platichthys flesus) showed different infection patterns between the two sampling periods. In 1968, 101 European flounders out of $147(69 \%)$ were infected with A. cornuta. Infected flounders had a mean size of $235 \mathrm{~mm}$ ( \pm SD 55.9) and were host to an average of $6.3( \pm 5.5)$ A. cornuta. Fish sampled in 2010 were smaller, containing proportionally fewer A. cornuta: 18 out of 40 (45\%) European flounders were infected and infected individuals had an average size of $182 \mathrm{~mm}( \pm 41.2)$ and hosted an average of $3.2 \pm 1.8 \mathrm{~A}$. cornuta. While a $\chi^{2}$ test indicated a significant difference in prevalence between the two periods $(P=0.006)$, the ANCOVA did not show a difference in intensity between the years (Table 3). Only host size had a significant effect on A. cornuta infection levels and the non-significance of the interaction term indicated a similar slope of the size-infection level relationship in both periods (Figure 2; Table 3). Density of infected fish and density of copepods increased from 1968 to 2010 (0.3-1.5 and 1.9-4.9 per day, respectively).

In contrast, $L$. pectoralis showed a more marked change in infection patterns from 1968 to 2010. In 1968, 115 European flounders out of 152 (76\%) were infected with L. pectoralis. Infected flounders measured on average $230 \mathrm{~mm}( \pm 55.0)$ and were host to an average of $6.2( \pm 5.1)$ L. pectoralis. In 2010, mean host size was only $149 \mathrm{~mm}( \pm 58.2)$ on average, but still 34 out of 40 (85\%) flounders were infected with
L. pectoralis, and at a higher per-host abundance (10.3 $\pm 9.3)$. While a $\chi^{2}$ test indicated no significant difference in prevalence between the two periods $(P=0.207)$, the ANCOVA revealed a significant effect of host size (Table 3 ). More importantly, the significance of the interaction term (size $\times$ year) indicated a difference in slope of the size-infection level relationship between the periods (Figure 3; Table 3). In 2010, L. pectoralis infected smaller hosts, and with higher infection intensity at a given host size than in 1968 (Figure 3). Density of infected fish and density of copepods increased more markedly compared to A. cornuta from 1968 to 2010 (0.3-2.9 and $2.1-30.6$ per mean daily catches, respectively).

The data from the fyke showed clear changes in flounder abundance with highest daily catches between the late 1970 s and early 1990 s (up to 140 ind. $\mathrm{d}^{-1}$ ) and low daily catches (below 20 ind. $\mathrm{d}^{-1}$ ) since then (Figure $4 \mathrm{~A}$ ). In addition, catches in the 1960 s were, on average, higher than in recent times (Figure $4 \mathrm{~A}$ ). The size-frequency distribution patterns of flounders in the four periods reflected the high flounder abundances in the 1980 s (Figure $4 \mathrm{~B}$ ). More importantly, while in the 1970s and 1980s large size-classes were still present, the larger size-classes strongly decreased in frequency from the 1990s onwards. In recent times, the catches were strongly dominated by small-sized individuals (Figure $4 \mathrm{~B}$ ). 


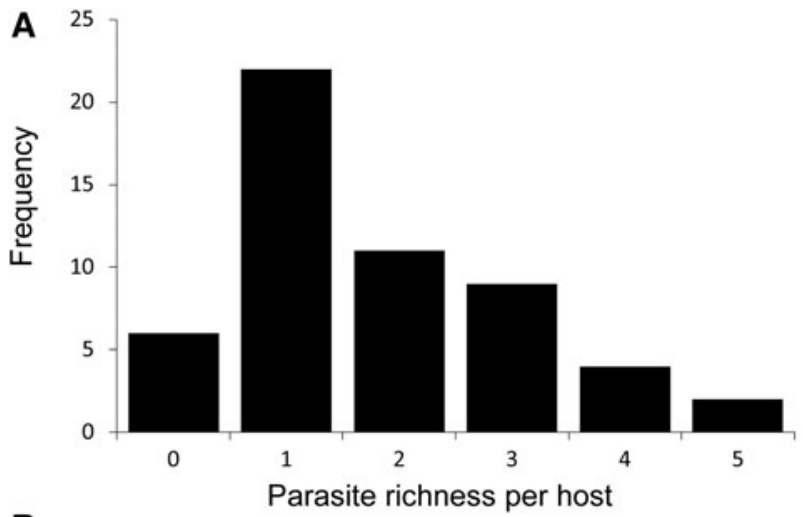

B

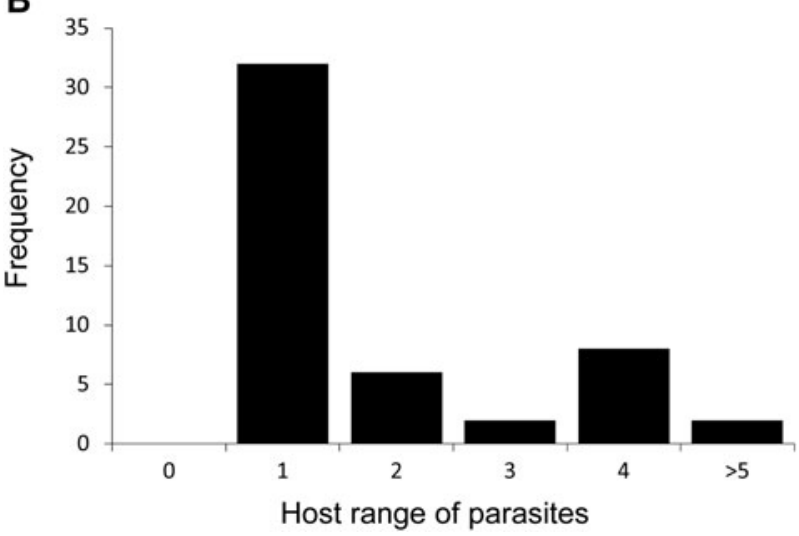

Fig. 1. Frequency distribution of (A) the total number of parasite species found per fish species (parasite richness per host) and (B) the number of fish species that a parasite species was found to infect (host range of parasite) in the western Dutch Wadden Sea.

\section{DISCUSSIDN}

This first inventory of parasitic copepods of fish in the western Wadden Sea to date revealed a rich parasite fauna, with 47 copepod parasite species found on 52 examined fish species. The observations in this study expand our knowledge from previous surveys in the North Sea region (Groenewold et al., 1996; Palm et al., 1999; Schmidt et al., 2003; Boxshall, 2009). In these
Table 3. ANCOVA results, testing for the effect of year (main effect) and host size (covariate) on copepod infection levels (log-transformed). The interaction term was added to test for differences in the slope of the size-infection level relationship between the two periods.

\begin{tabular}{lrrrr}
\hline Factor & df & MS & \multicolumn{1}{c}{ F } & \multicolumn{1}{c}{$\mathbf{p}$} \\
\hline A. cornuta & & & & \\
Year & 1 & 0.001 & 0.009 & 0.922 \\
Length & 1 & 5.852 & 45.619 & $<0.001$ \\
Year $\times$ Length & 1 & 0.005 & 0.040 & 0.842 \\
Error & 183 & 0.128 & & \\
L. pectoralis & & & & 0.418 \\
Year & 1 & 0.084 & 0.659 & 0.001 \\
Length & 1 & 10.381 & 81.697 & 0.012 \\
Year $\times$ Length & 1 & 0.812 & 6.392 & \\
Error & 188 & 0.127 & & \\
\hline
\end{tabular}

reports, another 37 fish species were investigated that were not examined in our study, including the orders Syngnathiformes (five species, all without copepods) and Perciformes (15 species, only a few with copepods). These studies furthermore report 19 copepod species not found in this survey, including Ergasilidae and Eudactylinidae (with three species reported from each of these families). About half (23 out of 47 , see Table 2) of the copepod species found in our study were not present in previous reports from the North Sea region, including all findings of Cecropidae (three species) and Sphyriidae (two species). Of these 23 additional copepod species, 13 were found on one of the eight host species not examined in the earlier reports (see Table 1), although none of these host species are particular to the Wadden Sea. Hence, while there is considerable overlap with other studies from the North Sea region, about half of the copepod species found in our study area are new findings that can probably be ascribed to both the inclusion of other host species, and the specific parasite fauna in the western Dutch Wadden Sea. Overall, the number of copepod species found is similar to the ones found in surveys from other regions (e.g. Mexican coastal fish: Causey, 1960). Large studies, sampling a larger array of fish species and individual hosts, have however, found higher numbers of parasite species especially when a large percentage of examined

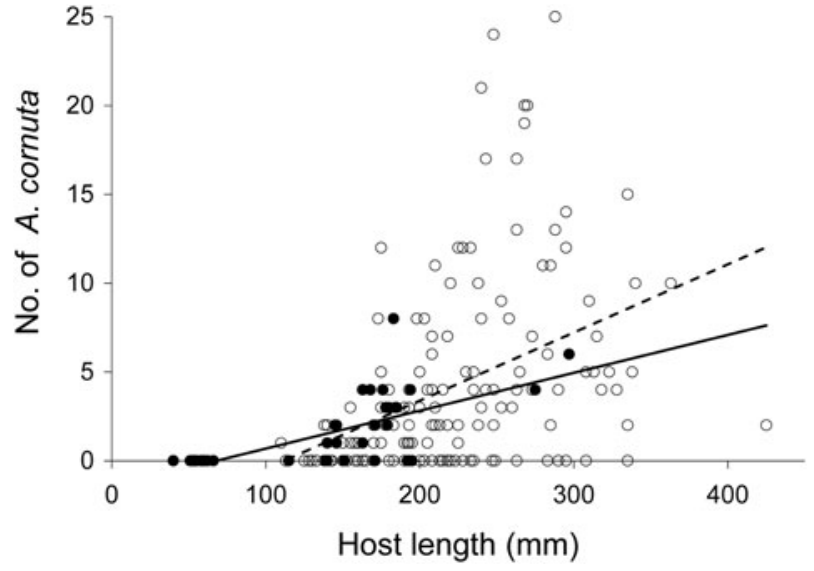

Fig. 2. Number of Acanthochondria cornuta on Platichthys flesus versus host fork length $(\mathrm{mm})$ in the western Dutch Wadden Sea. Open dots and dashed trend line represent 1968 data, filled dots and solid trend line represent data from 2010.

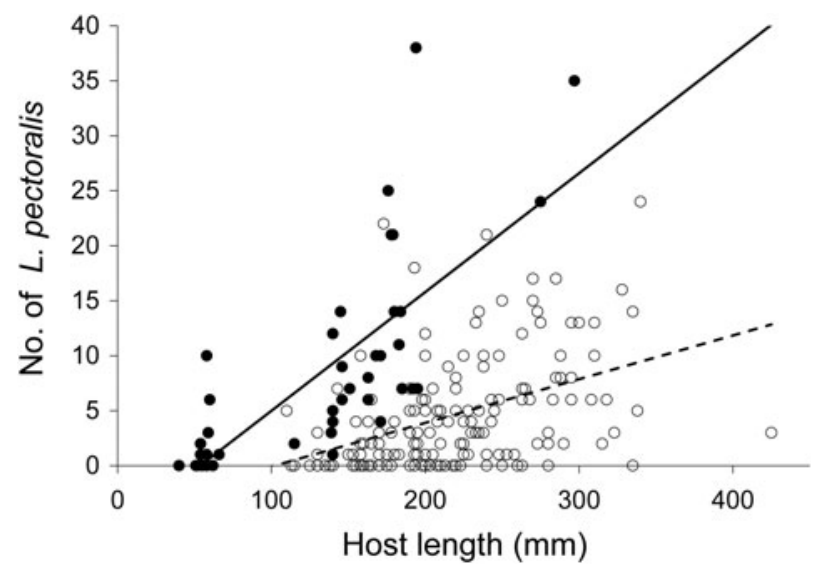

Fig. 3. Number of Lepeophtheirus pectoralis on Platichthys flesus versus host fork length $(\mathrm{mm})$ in the western Dutch Wadden Sea. Open dots and dashed trend line represent 1968 data, filled dots and solid trend line represent data from 2010. 


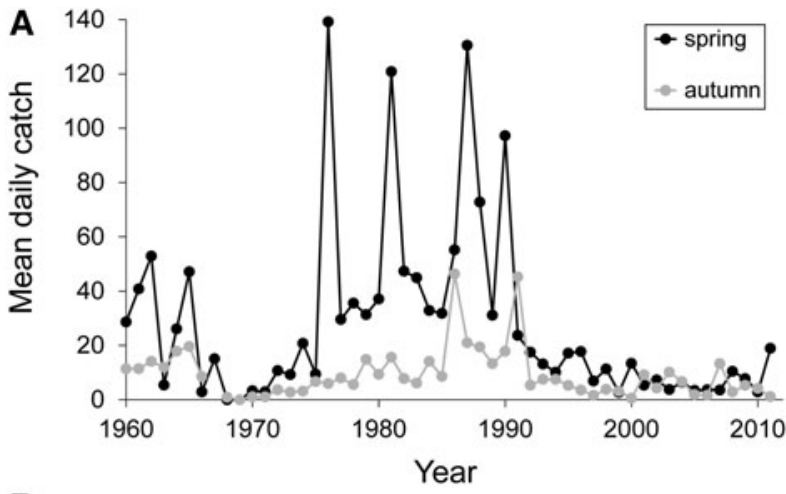

B

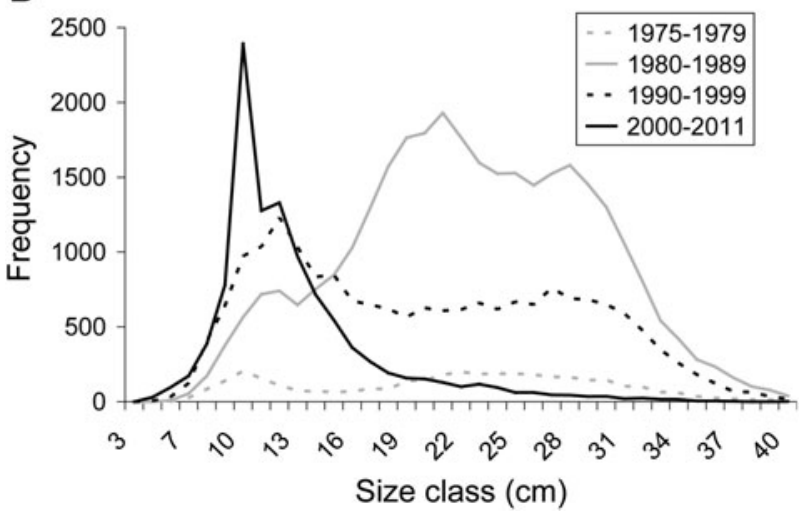

Fig. 4. Long-term trends of European flounders (Platichthys flesus) in (A) abundance (mean daily catch; ind. $\mathrm{d}^{-1}$ ) in spring (April-June) and autumn (September-October) between 1960 and 2011; and (B) size-frequency distributions ( $2 \mathrm{~cm}$ steps) in four periods between 1975 and 2011 (19751979, 1980-1989, 1990-1999, 2000-2011). Data based on the NIOZ fyke net long-term time-series (for details see text).

hosts are nektonic and pelagic species, migratory and gregarious (e.g. Raibaut \& Combes, 1998). The observation that the sum of parasites found in a region greatly exceeds what is found in any single survey (Causey, 1960) further demonstrates that even the most extensive study is likely to find only a subset of parasite fauna present, as is likely to be the case here. In addition, the number of copepod species found is linked to the sampling effort per fish species. This suggests that our copepod inventory of the western Wadden Sea is not complete and that the number of host-parasite observations will increase when more host individuals and species are investigated.

The two parasite species infecting European flounders (Platichthys flesus) examined in more detail here, Acanthochondria cornuta and Lepeophtheirus pectoralis, exhibited different changes in infection patterns between 1968 and 2010. Whereas A. cornuta seems to show the same host size-parasite intensity relationship in both periods, L. pectoralis has shifted towards the infection of smaller hosts and higher infection levels at a given host size. The different patterns between the two copepod species probably result from both the properties of the parasites themselves and a shift in population structure of their host species. Acanthochondria cornuta is a parasite of the gill cavity, attaching to the gill arches, whereas $L$. pectoralis attaches to the skin of its host, where it is relatively mobile but usually found in close proximity to the fins (Kabata, 2003). With these specific life histories, the two copepods probably face different constraints in regard to general changes in the population structure of their hosts. The long-term data from the NIOZ fyke net showed a clear decrease of abundance and a shift toward smaller size-classes of flounders during the last decades (Van der Veer et al., 2011). This trend is in line with the general observation in many commercially harvested fish species which have become less abundant and tend to stay smaller as an adaptive response to the largest specimens being selectively fished out of the population (Rijnsdorp et al., 1996; Law, 2000; Daan et al., 2005; Jørgensen et al., 2007; Tulp et al., 2008). Both parasite species are thus confronted with a declining host density, and the available hosts are on average smaller than in 1968. As gill cavities are a much confined space, containing a fixed number of gill arches, $A$. cornuta may not be able to infect individuals at higher per-host abundance, nor infect individuals below a certain size, preventing it from compensating for the overall decline of host numbers. Indeed, intra-specific competition has been suggested for this species (Cavaleiro \& Santos, 2011), in particular because A. cornuta is a large species (body length 5-9 mm: Kabata (2003)) and only infects a limited area of the gills (Kabata, 1959; Cavaleiro \& Santos, 2011). In contrast, L. pectoralis does not face such intrinsic limitations and can potentially compensate for dwindling host abundance and smaller host size by simply infecting smaller fish as well as by increasing its per-fish abundance. Hence, the observed changes in infection patterns probably reflect general environmental changes in the form of sizeselective fishing pressure and dwindling fish stocks. Interestingly, the overall population size of copepods does not seem to suffer from a reduced number and size of fish hosts, because in both species the overall density of infected fish and copepods increased from 1968 to 2010. However, our measures of fish abundance may be too coarse to make strong inferences. Besides affecting infection levels of parasites, changes in fish size and abundance may also affect parasite life history traits (Poulin, 1996). For example, with a decreased abundance and size of hosts, selection might favour female copepods that mature at smaller body sizes, and that produce more and smaller eggs, but, due to a lack of data for our species, this remains to be investigated.

The changes in infection patterns observed in the two copepod species are striking and consistent with general fish stock changes in the study area, but we acknowledge that our study was restricted to only two points in time and thus limited in temporal scope. In general, to monitor and identify trends in infection levels, a continuous data series would be preferable. However, such time series on parasite infection patterns are very rare and logistically challenging (Wood et al., 2010). Our snapshot approach is valuable nonetheless, in particular because it links patterns in parasite infection levels with changes in host abundance and size. There are various other environmental parameters, such as temperature, pollutants, hunting- and fishing regulations, invasive species and recreational activity, that are known to have changed during the last decades in the study area (Lotze et al., 2005, Reise \& Van Beusekom, 2008). Some of those changes might offer alternative explanations for the observed patterns in the two copepod species, and we cannot rule out that some of these other variables might drive the temporal patterns we detected. In general, a combination of parasite-time series with time-series on environmental factors will be helpful to link observed patterns with underlying process. Combined with experimental studies on the effects of environmental changes on parasite infection parameters such correlative 
field studies on parasite infection patterns may become helpful tools to trace broad-scale environmental changes in the future (Vidal-Martinez et al., 2010; Wood et al., 2010).

\section{ACKNDWLEDGEMENTS}

Thanks are due to all those who assisted over the years in setting up, maintaining and emptying the komfyke, especially to the late Henk Beumkes, Willem Jongejan, Ewout Adriaans and Sieme Gieles. We also thank the referees for their comments on the manuscript.

\section{REFERENCES}

Bere R. (1936) Parasitic copepods from Gulf of Mexico fish. American Midland Naturalist 17, 577-625.

Boxshall G.A. (2009) Infections with parasitic copepods in North Sea marine fish. Journal of the Marine Biological Association of the United Kingdom 54, 355-372.

Causey D. (1960) Parasitic copepoda from Mexican coastal fishes. Bulletin of Marine Science 10, 323-337.

Cavaleiro F.I. and Santos M.J. (2011) Site selection of Acanthochondria cornuta (Copepoda: Chondracanthidae) in Platichthys flesus (Teleostei: Pleuronectidae). Parasitology 138, 1061-1067.

Daan N., Gislason H., Pope J.G. and Rice J.C. (2005) Changes in the North Sea fish community: evidence of indirect effects of fishing? ICES Journal of Marine Science 62, 177-188.

Dogiel V.A., Petrushevski G.K. and Polyanski Y.I. (1953) Parasitology of fishes (translated by Kabata Z. (1961)). Edinburgh: Oliver \& Boyd.

Groenewold S., Berghahn R. and Zander C.D. (1996) Parasite communities of four fish species in the Wadden Sea and the role of fish discarded by the shrimp fisheries in parasite transmission. Helgoländer Meeresuntersuchungen 50, 69-85.

Hechinger R.F., Lafferty K.D. and Kuris A.M. (2008) Trematodes indicate animal biodiversity in the Chilean intertidal and Lake Tanganyika. Journal of Parasitology 94, 966-968.

Heegaard P. (1962) Parasitic copepoda from Australian waters. Records of the Australian Museum 25, 149-233.

Jørgensen C., Enberg K., Dunlop E.S., Arlinghaus R., Boukal D.S. Brander K., Ernande B., Gærdmark A., Johnston F., Matsumura S., Pardoe H., Raab K., Silva A., Vainikka A., Dieckmann U., Heino M. and Rijnsdorp A.D. (2007) Managing evolving fish stocks. Science 318, 1247-1248.

Kabata Z. (1959) Ecology of the genus Acanthochondria Oakley (Copepoda Parasitica). Journal of the Marine Biological Association of the United Kingdom 38, 249-261.

Kabata Z. (1979) Parasitic copepoda of British fishes. London: The Ray Society.

Kabata Z. (2003) Copepods parasitic on fishes. In Synopses of the British Fauna 47. Shrewsbury: Field Studies Council.

Kleinertz S., Klimpel S. and Palm H.W. (2011) Parasite communities and feeding ecology of the European sprat (Sprattus sprattus L.) over its range of distribution. Parasitology Research 110, 1147-1157.

Krkošek M., Connors B.M., Morton A., Lewis M.A., Dill L.M. and Hilborn R. (2011) Effects of parasites from salmon farms on productivity of wild salmon. Proceedings of the National Academy of Sciences of the United States of America 108, 14700-14704.
Krkošek M., Ford J.S., Morton A., Lele S., Myers R.A. and Lewis M.A. (2007) Declining wild salmon populations in relation to parasites from farm salmon. Science 318, 1772-1775.

Law R. (2000) Fishing, selection, and phenotypic evolution. ICES Journal of Marine Science 57, 659-668.

Lotze H.K., Reise K., Worm B., van Beusekom J., Busch M., Ehlers A., Heinrich D., Hoffmann R.C., Holm P., Jensen C., Knottnerus O.S., Langhanki N., Prummel W., Vollmer M. and Wolff W.J. (2005) Human transformations of the Wadden Sea ecosystem through time: a synthesis. Helgoland Marine Research 59, 84-95.

Möller H. and Anders K. (1986) Techniques in fish parasitology. In Möller H. and Anders K. (eds) Diseases and parasites of marine fishes. Kiel: Möller, pp. 331-339.

Mouritsen K.N. and Poulin R. (2002) Parasitism, community structure and biodiversity in intertidal ecosystems. Parasitology 124 $\mathrm{S}_{101-\mathrm{S}_{117} \text {. }}$

Palm H.W., Klimpel S. and Bucher C. (1999) Checklist of metazoan fish parasites of German coastal waters. Berichte aus dem Institut für Meereskunde an der Christian-Albrechts-Universität Kiel 307, $148 \mathrm{pp}$.

Poulin R. (1996) The evolution of life history strategies in parasitic animals. Advances in Parasitology 37, 107-134

Poulin R., Krasnov B.R., Mouillot D. and Thieltges D.W. (2011) The comparative ecology and biogeography of parasites. Philosophical Transactions of the Royal Society B 366, 2379-2390.

Raibaut A. and Combes C. (1998) Analysis of the parasitic copepod species richness among Mediterranean fish. Journal of Marine Systems 15, 185-206.

Reise K. and van Beusekom J. (2008) Interactive effects of global and regional change on a coastal ecosystem. Helgoland Marine Research $62,85-91$

Rijnsdorp A.D., van Leeuwen P.I., Daan N. and Heessen H.J.L. (1996) Changes in abundance of demersal fish species in the North Sea between 1906-1909 and 1990-1995. ICES Journal of Marine Science $53,1054-1062$.

Schmidt V., Zander S., Körting W. and Steinhagen D. (2003) Parasites of the flounder Platichthys flesus (L.) from the German Bight, North Sea, and their potential use in ecosystem monitoring. A. Infection characteristics of potential indicator species. Helgoland Marine Research 57, 236-251.

Scott T. and Scott A. (1912) The British parasitic copepoda, vol. I and II. London: The Ray Society.

Sousa W.P. (1991) Can models of soft-sediment community structure be complete without parasites? American Zoologist 31, 821-830.

Sukhdeo M.V.K. (2012) Where are the parasites in food webs? Parasites \& Vectors 5, 239.

Tully O. and Nolan D.T. (2002) A review of the population biology and host-parasite interactions of the sea louse Lepeophtheirus salmonis (Copepoda: Caligidae). Parasitology 124, 165-182.

Tulp I., Bolle L.J. and Rijnsdorp A.D. (2008) Signals from the shallows: in search of common patterns in long-term trends in Dutch estuarine and coastal fish. Journal of Sea Research 60, 54-73.

van der Meer J., Witte J.IJ. and van der Veer H.W. (1995) The suitability of a single intertidal fish trap for the assessment of long-term trends in fish and epibenthic invertebrate populations. Environmental Monitoring and Assessment 36, 139-148.

van der Veer H.W., Witte J.IJ., Beumkes H.A., Dapper R., Jongejan W.P. and van der Meer J. (1992) Intertidal fish traps as a tool to study long-term trends in juvenile flatfish populations. Netherlands Journal of Sea Research 29, 119-126. 
van der Veer H.W., Koot J., Aarts G., Dekker R., Diderich W., Freitas V. and Witte J.IJ. (2011) Long-term trends in juvenile flatfish indicate a dramatic reduction in nursery function of the Balgzand intertidal Dutch Wadden Sea. Marine Ecology Progress Series 434, 143-154.

Vidal-Martinez V.M., Pech D., Sures B., Purucker S.T. and Poulin R. (2010) Can parasites really reveal environmental impact? Trends in Parasitology 26, 44-51.

and
Wood C.L., Lafferty K.D. and Micheli F. (2010) Fishing out marine parasites? Impacts of fishing on rates of parasitism in the ocean. Ecology Letters $13,761-775$.

Correspondence should be addressed to:

D. W. Thieltges

Department of Marine Ecology; NIOZ Royal Netherlands Institute for Sea Research; PO Box 59, 1790 AB Den Burg Texel, The Netherlands

email: David.Thieltges@nioz.nl 